\title{
SOCIAL ENGINEERING THROUGH SHARI'A: ISLAMIC LAW AND STATE-DIRECTED DA'WA IN CONTEMPORARY ACEH
}

\author{
R. Michael Feener*
}

\begin{abstract}
This study of the contemporary Islamic legal system in Aceh, Indonesia argues for new attention to be paid to the ways in which contemporary Muslim agendas for the implementation of Islamic law can be read as projects for futureoriented social transformation-rather than as a series of reactive measures to perceived 'crises of modernity' and/or the political machinations of rival elites in contesting control of state power. In doing so it highlights the ways in which the ideals of, and institutional formations developed by, proponents of Islamic law are configured in relation to a broad range of non-Muslim modernist projects, including European and American theories of the sociology of law. rough examinations of these influences on discussions of Islamic law in Aceh, this essay demonstrates the degrees to which contemporary Sharīa implementation is inextricably linked to broader configurations of law, moral authority, and state power in the modern global order.
\end{abstract}

Keywords: Islamic law, Social Engineering, Technocrats, Reconstruction, Development, Indonesia

\section{Introduction}

The special autonomous region of Aceh, Indonesia, is home to one of the most complex experiments with the implementation of Islamic law in the contemporary world. Originally proposed by the Indonesian central government as a measure to put an end to an armed separatist revolt, the state project for the implementation of Islamic law in the province was advanced rapidly in the wake of the devastating 2004 earthquake and tsunami. In this context, the Sharīa agenda was significantly reenergized in ways that dramatically highlighted one of its central aspects: that of using Islamic law as an instrument of social engineering. Based on a critical analysis of the ways that the state implementation of Islamic law has been configured and pursued in the context of post tsunami/post conflict Aceh, I argue for a re-alignment of analytic perspective in which contemporary Muslim calls for the implementation of Islamic law can be read as projects for future oriented social transformation-rather than as a series of reactive measures to perceived 'crises of modernity' and/or the political machinations of rival elites in contesting control of state power.

\section{Islamic Law in Aceh}

After Indonesia initiated its 'Reformasi' decentralization process in 1999, Aceh was granted the authority to formally implement Islamic law in the province. ${ }^{1}$ Law No. 44/1999 formally recognized the 'Special Status

Correspondence: R. Michael Feener, Asia Research Institute, National University ofSin- 
of the Province of Aceh Special Region' in the fields of religion, education, and customary law (adat), and Law No. 18/2001 conferred in principle broader powers of self-governance in areas including religion and provincial legislation. This made it possible to develop more vigorous Sharì' a regulations by allowing the local legislative assem bly to move forward with working out the details of new legislation (qanun), including those defining the new institutions by which Islamic law would be implemented. ${ }^{2}$ Aceh's current Sharìa bureaucracy comprises a number of distinct but interrelated bodies. In this system, the State Sharīa Agency ( Dinas Syariat Islam/DSI) performs coordinating functions in working with the other major institutions involved with the implementation of Islamic law in contemporary Aceh: the Sharīa Courts (Mahkamah Syariah/MS), the Ulama Council (Majlis Permusyawaratan Ulama/MPU), the 'Sharīa Police' (Wilayatul Hisbah/WH). ${ }^{3}$

The substantive legislation of Islamic law in Aceh is contained in regional regulations referred to locally as 'qanun'.4 Aside from two qanuns dealing with the formation of specific Shari'a institutions, ${ }^{5}$ the first of these new laws passed was Qanun No. 11/2002, which marked a new level of symbolic state engagement with the particulars of Islamic belief and practice. In terms of formal law enforcement, however, the most significant Acehnese qanuns

gapore, 469A Tower Block, '10-01, Bukit Timah Road, Singapore, 259770. E-mail: arifm@nus. edu.sg

* I have presented earlier versions of this essay at workshops and seminars at Columbia University (New York), Institut d'études de l'Islam et des sociétés du monde Musulman (Paris), Universitas Al Muslim (Bireuen, Aceh), Universitas Malikussaleh, and STAIN (both in Lhokseumawe, Aceh) and I have benefitted much from the comments of colleagues in these discussions. I would also like to thank Merle Ricklefs, Chaider Bamualim, Mahdi Syihab, Mark Cammack, Barry Hooker, Jeremy Kingsley, David Powers, and the anony mous reviewers of this journal for their comments on earlier drafts of this paper. My thanksalso to Hongyan Li for her help with formatting the manuscript for publication. Research for this project was undertaken with the support of a grant from the Singapore Ministry of Education's Academic Research Fund (MOE AcRF 'R-110-000-029-750)

1 For a brief background on legal and administrative reform in the post-Suharto period, see Tim Lindsey and Mas Achmad Santosa, " e Trajectory of Law Reform in Indonesia: A Short Overview of Legal Systems and Change in Indonesia," in Indonesia: Law and Society, 2nd edition, ed. Tim Lindsey (Annandale, Australia: Federation Press, 2008), 11 -22. For the broader social and political contexts of Indonesian 'Reformasi', see Kees van Dijk, ACountry in Despair: Indonesia between 1997 and 2000 (Leiden: KITLV Press, 2001), 289-321.

2 On the political contexts surrounding the initial implementation of Islamic law in contemporary Aceh, see further the chapters by Moch. Nur Ichwan and Tim Lindsey, M.B. Hooker, Ross Clarke, and Jeremy Kingsley in Islamic Law in Contemporary Indonesia:Ideas and Institutions, ed. R. Michael Feener and Mark E. Cammack (Cambridge: HarvardUniversity Press, 2007), 193-254, and Michelle Miller and R. Michael Feener, "Emergency and Islamic Law in Aceh," in Law and Emergency Powers in Asia: Exploring the Limits ofLegality, ed. Victor Ramraj and Arun iruvengadam (Cambridge University Press, 2010),213-36.

3 Each of these institutions is discussed in detail in my forthcoming book, Sharī”a as SocialEngineering: e Implementation of Islamic Law in Contemporary Aceh, Indonesia.

4 The standard published source for legislation on the implementation of Islamic law in contemporary Aceh is Himpunan Undang-undang, Keputusan Presiden, Peraturan Daerah/Qanun, Instruksi Gubernur dan Edaran Gubernur berkaitan Pelaksanaan Syari"at Islam, EdisiKetujuh (Banda Aceh: Dinas Syari'at Islam Aceh, 2009).

5 Peraturan Daerah Provinsi Nanggroe Aceh Darussalam No. 33/2001 tentang Susunan Organisasi dan Tata Kerja Dinas Syariat Islam; and Qanun Provinsi Nanggroe Darussalam No. 10/2002 tentang Peradilan Syariat Islam. This explanation of the term is borrowed from William Roff's work on similar regulations of Islamic morality in the Malay Peninsula. See his "Patterns of Islamization in Malaysia, 1890s1990s: Exemplars, Institutions and Vectors," Studies of Islam and Society in SoutheastAsia (Singapore: NUS Press, 2009), 98. 
have been three laws passed in 2003: No. 12 on the consumption of alcohol, No. 13 on gambling, and No. 14 on khalwat (improper covert association" between members of the opposite sex). 6 As the only substantive statements on the content of Sharia to be applied in Aceh to date, these have been the focus of most of the new activities of the Sharīa Courts and the other new, or newly reformulated, institutions of Islamic law there. ${ }^{6}$ Within this rather limited range of Sharı'a 'criminal' offenses (jinayat), however, cases involving gambling, alcohol consumption and khalwat have never, to date, amounted to a significant portion of the Mahkamah Syariah's caseload. Across Aceh, there has been a sharp decrease in the number of cases involving qanuns No. 12, No. 13 , and No. 14 since numbers peaked in 2005-2006. ${ }^{7}$

The operationalization of many parts of Aceh's contemporary Islamic legal system has been hampered by various physical, political, and social constraints. Thus despite the establishment of a number of institutions dedicated to the application of Sharì'a as positive law, the impact of their work in the actual implementation of law in the province has been minimal. What then, are we to make of a legal system that does not actually do very much law in the formal sense? I argue that the architects and institutional agents of Aceh's contemporary Sharìa system have increasingly directed their attention and resources away from the promulgation of new legislation and the prosecution of cases and toward strategies for the more informal 'socialization' of a particular set of Islamic values. Their approach has thus been to work toward a more fundamental transformation of Acehnese society that extends well beyond blackletter law and the state institutions of the formal legal sphere. In this, we find a situation in which the legal program of state Sharīa implementation has been subsumed within a broader array of movements for reforming society in accordance with Islamic norms. This has resulted in a significant blurring of any clear distinction between the spheres of Islamic law and $d a " w a$. Here the power of legal institutions is brought to bear less on the application of positive law than it is to provide state support for programs of religious and social reconstruction.

\section{III.Building a 'New Aceh'}

The massive destruction wrought by the 2004 tsunami leveled many existing structures, both physical and organizational. ${ }^{8}$ At the same time it opened up space for rebuilding Acehnese society from the ground up, and this in turn established the highly charged context in which the implementation of Aceh's contemporary Islamic legal system took place. ${ }^{9}$ This work was greatly

6 the courts have had far fewer cases related to the subsequent Qanun No. 7/2004 on Zakat.

It should also be noted that over the years the number of cases prosecuted in each of Aceh's twenty-four first-instance Islamic courts has varied widely from district to district, and that even during the peak years immediately following the tsunami the overwhelming majority of them never handled double digit criminal caseloads. 'Rekapitulasi Pelanggaran Qanun Jinayah dengan Hukuman Cambuk sejak tahun 2004 s/d 2010 oleh Mahkamah Syari'ah se-Wilayah Aceh," statistics compiled by Khudaini (Mahkhamah Syari'iyah Kabupaten Aceh Besar, Jantho), April 2011.

8 The M9.2 earthquake on December 26, 2004 caused a tsunami that struck the coast of Aceh, leaving over 122,000 dead or missing and displacing over 700,000 survivors. For more on the extent of physical destruction, see Consultative Group on Indonesia, Preliminary Damage and Loss Assessment: e December 26, 2004 Natural Disaster (Jakarta:BAPPENAS, 2005).

On the reconstruction and peace processes in Aceh, see Patrick Daly, R. Michael Feener, and 
facilitated by the fact that the natural disaster and international responses to it catalyzed and accelerated efforts toward settlement of a peace accord that ended the decades long violent conflict between GAM (Gerakan Aceh Merdeka/"Free Aceh Movement") and the central Indonesian government. ${ }^{10}$ The newly established peace also allowed governments and a host of diverse non-governmental organizations to pursue their own projects of relief, rehabilitation and development largely undisturbed by the kinds of violence that previously had made such interventions nearly impossible in Aceh. ${ }^{11}$ In doing so, it also allowed for the entry of large numbers of foreign aid workers who brought with them a wide range of ideas on reconstruction in addition to immediate disaster relief. ${ }^{12}$

Although the efforts of international aid programs were diverse in many ways, they generally shared a broader discursive framework that emphasized goals of linking relief, rehabilitation and development (LRRD) in response to the disaster. This rhetoric of transformation builds upon global discourses of developmentalism promoted by government agencies and organizations like the World Bank. A defining trope of this vision of disaster relief and recovery is an emphasis on the importance of going beyond immediate post disaster recovery and using the opportunity to develop infrastructure, and to develop new modes of good governance that emphasize capacity building and sustainability. ${ }^{13}$

To coordinate the vast and diverse reconstruction efforts of international aid projects, and to facilitatelinks between relief, rehabilitationand development in response to the disaster, the Indonesian government established a special, ministry level body known as the Rehabilitation and Reconstruction Agency for Aceh and Nias (Badan Rehabilitasi dan Rekonstruksi/BRR).${ }^{14}$ The BRR was given a fixed, four year mandate of operations by the Indonesian government, and a symbolic charge by former US President Bill Clinton (in his capacity as the UN Special Envoy for Tsunami Recovery), to "build back better." ${ }^{15}$ This included not only the physical reconstruction of disaster affected areas, but also efforts to implement new models of quality assurance, transparency, good

Anthony Reid, ed., From the Ground Up: Perspectives on Post Tsunami and Post ConflictAceh (Singapore: ISEAS Press, 2011).

10 Earlier attempts at resolving the conflict were plagued by difficulties. See Edward Aspinall and Harold A. Crouch, "e Aceh Peace Process: Why it Failed," East-West CenterPolicy Studies (Washington, D.C.: East-West Center, 2003); Michelle Ann Miller, Rebellion and Reform in Indonesia: Jakarta's Security and Autonomy Policies in Aceh (London: Routledge,2009). Diverse aspects of the peace process that culminated in the 2005 Helsinki agreement are presented in the papers published in Aguswandi and Judith Large, ed., ReconfiguringPolitics: e Indonesia-Aceh Peace Process-a special issue of Accord: An International Review of Peace Initiatives 20 (2008). For a critical review of the longer process, see Ed Aspinall, Islam and Nation: Separatist Rebellion in Aceh, Indonesia (Singapore: NUS Press, 2009),220-47.

11 Badan Rehabilitasi dan Rekonstruksi (BRR) and International Partners, Aceh and NiasOne Year after the Tsunami: e Recovery Effort and Way Forward (Banda Aceh: BRR NAD-Nias, 2005), 14-5, 116-7.

12 J. Telford, J. Cosgrove, and R. Houghton, Joint Evaluation of the International Responseto the Indian Ocean Tsunami: Synthesis Report (London: Tsunami Evaluation Coalition,2006).

13 See, for example: Multi Donor Fund, Implementing Projects, Achieving Results: 18 Monthsof the Multi Donor Fund for Aceh and Nias-Progress Report III (Jakarta: 2006).

14 The BRR was formally established on April 16, 2005 "as a coordinating agency to ensure transparency, accountability, and speed in the reconstruction of Aceh and Nias." BRR FactSheet (Ref. 1003/10/3/ BRRFactSheet-E.doc).

15 Badan Rehabilitasi dan Rekonstruksi (BRR) and International Partners, Aceh and Nias:Two Years after the Tsunami: 2006 Progress Report (Banda Aceh: BRR NAD-Nias, 2006),iii. 
governance, and gender equity in post tsunami Aceh. ${ }^{16}$ In fact, of the originally proposed multi billion dollar reconstruction budget, only half was directly allocated for humanitarian relief and reconstruction of facilities destroyed by the earthquake and tsunami. The remainder was budgeted "to address long standing problems and for building a better Aceh" (emphasis in original). ${ }^{17}$

Since 2005, this rhetoric of radical reconstruction spread across Aceh, far beyond the coastal areas affected by the tsunami. The BRR's reports and literature went so far as to proclaim: "The tsunami proved to be a blessing in disguise for Nanggroe Aceh Darussalam. It transformed this westernmost province of Indonesia. Not just physically either..." ${ }^{18}$ Combined with the euphoric discourses surrounding the dawn of a new peace in a region long plagued by violent conflict, there emerged a pervasive sense of the possibility of creating a 'new Aceh' that would transform the lives of a people who had suffered so much war and devastation.

What this new and improved Aceh might look like, however, was a subject of extensive debate in an energized public sphere. With the ending of armed conflict, Aceh, for the first time, was able to enjoy the new freedoms of post Suharto Indonesia. This allowed local newspapers, magazines and broadcast media to flourish, and facilitated the emergence of hotly contested debates on a wide range of social, legal, and political issues..$^{19}$ At the same time, the great influx of NGOs and foreign aid organizations into post conflict, post tsunami Aceh brought new perspectives and voices to these conversationsoften emphasizing concerns central to their own views on how restoring livelihoods and economic development could contribute to the promotion of broader social improvements toward human rights, gender justice and democratization. ${ }^{20}$ Their ideas were vigorously promoted not only through publications, but also through thousands of outreach sessions, focus group discussions, seminars and workshops that cluttered the calendar of events in Aceh for most of 2005-2009. Through such programs, increasing numbers of Acehnese became engaged with debates over new ideas about peace, human rights, gender justice, democracy and economic development. In many cases, these discussions also engaged with the implications of these ideas for local understandings of Islam.

16 Aceh and Nias: 2006 Progress Report, 84-8.

17 World Bank, Rebuilding a Better Aceh and Nias: Preliminary Stocktaking of theReconstruction Effort Six Months After the Earthquake and Tsunami (Jakarta: 2005), xv. einitial projections and plans for the allocation of reconstruction aid funds were, of course, reworked as priorities shifted. For an account of the handling of these funds up until the end of the BRR's mandate in 2009, see BRR, Finance: e Seven Keys to Effective AidManagement (Jakarta: Multi Donor Fund/UNDP, 2009).

18 BRR, Tsunami: From Disaster to the Emergence of Light (Jakarta: Multi Donor Fund/ UNDP, 2009), 95.

${ }^{19}$ R. Michael Feener, "Hand, Heart and Handphone: State Sharīa in the Age of the SMS," (forthcoming).

20 The immense amount of funding available for reconstruction in post tsunami Aceh created an unprecedented opportunity for various aid organizations to implement and test theories about disaster mitigation and vulnerability that they had been developing since the 1990s. ese developments are discussed further in Patrick Daly, Zero Hour: Post disasterRecovery and Reconstruction (forthcoming). 


\section{Post Tsunami Religious Revival}

Concurrent with these burgeoning discussions in NGO circles was a broad surge of religious revival in post tsunami Aceh. In an initial mapping of Acehnese interpretations of the earthquake and tsunami, it was noted that while some saw them as purely natural disasters, many Acehnese understood the tragedy as originating from God, either as divine retribution for the sins of the people, a test of their faith, or something preordained. ${ }^{21}$ Published collections of tsunami survivor narratives contain numerous accounts framed in expressly religious terms, with frequent references to the ways in which mosques-often the only buildings to survive the shocks of quake and

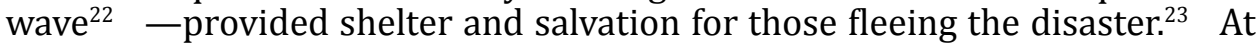
the same time, official publications from the Acehnese provincial government elaborate upon what were perceived to be God's meaning and purpose behind such disasters, including: (1) to raise the quality of religious faith, (2) an opportunity for those struck by tragedy to gain religious merit, (3) a means of having one's sins forgiven, (4) an occasion for God to grant mercy to those who are patient and accepting of fate, and, (5) a divine test to determine who truly has faith-"like gold that is tested by fire to separate the pure from the false."24

Religious dimensions of social change were energetically engaged by the state and other major players behind the transformations of post tsunami Aceh. In this way, the reconstruction efforts gave supporters of the Sharìa program new momentum with which to restart stalled measures for the implementation of Islamic law in the province. This new refocusing on religion as a major component of social change was supported by the Indonesian government at the highest levels. For example, the Consultative Group on Indonesia-composed of leaders from the Indonesian National Planning Development Agency (BAPPENAS), the World Bank, and the international donor committee- designated "Supporting Religion and Culture" as a major rubric for reconstruction efforts in the immediate wake of the tsunami. ${ }^{25}$ The BRR went even further in actively encouraging transformation in the religious and cultural life of post tsunami Aceh: the risks were too great for BRR to focus merely on rebuilding damaged houses and infrastructure. e agency also needed to facilitate social transformation, and therefore geared all its programs and activities toward achieving social reconstruction... To achieve the above, BRR, in particular the Deputy for Religious, Social and Cultural Affairs, coordinated, developed and promoted cross sectoral activities to strengthen and renew the

21 Julianto Saleh, "Pemaknaan Kejadian Tsunami dan Perilaku Keberagamaan Masyarakat Pasca Tsunami” (Banda Aceh: Pusat Latihan Penelitian Ilmu-Ilmu Sosial, 2005).

22 According to more worldly explanations for the survival of mosques amid the destruction of other buildings, the open design and/or more solid materials used in mosque construction accounted for their survival while surrounding neighborhoods were levelled by the wave.

${ }_{23}$ See, for example, Damanhuri bin Abbas et al., Tsunami dan Kisah Mereka (Banda Aceh: Badan Arsip Provinisi NAD, 2006); Sri Widodo and Ikhwan Nursyujoko, ed., 99 TanganTuhan di Aceh: Misteri dan Keajaiban di Balik Tsunami (Jakarta: Yayasan Air Mata, 2005).

24 Teuku Abdullah Sanny, ed., Tsunami Aceh (Banda Aceh: Pemerintah Provinsi Nanggroe Aceh Darussalam, 2008), 157-63. On religious interpretations of the tsunami in Aceh, see Edwin Wieringa, "God Speaks through Natural Disasters, but What Does he Say?: Islamic interpretations in Indonesian Tsunami Poetry," in Aceh History, Politics and Culture, ed. Arndt Graf, Susanne Schröter, and Edwin Wieringa (Singapore: ISEAS Press, 2010), 316-33.

25 Consultative Group on Indonesia, Notes on Reconstruction: e December 26, 2004Natural Disaster (Jakarta: BAPPENAS, 2005), 45-53. 
spiritual and social life of the people. ${ }^{26}$

The Indonesian Government's initial 'Master Plan' also identified specific policy strategies for addressing religious aspects of the reconstruction of post tsunami Aceh, with particular focus on religious education, the recruitment and training of religious officials, the construction of mosques and offices for state religious bureaucracies, and fostering 'spiritual tranquility recovery'. ${ }^{27}$ These projects for religious reconstruction had the effect of bringing Islamic institutions and leadership further into the orbit of the Indonesian state in complex ways. Through these newly strengthened connections, the ulamā' were engaged and employed as the means by which to promote a new social vision of Islam in Aceh. For example, a workshop for female "ulamā hosted at Banda Aceh's most luxurious new hotel in June 2007 recommended, inter alia , that "theulamāmust be resolute toward the government onthe issue of Shari'a implementation and more pro active in society in promoting the understanding of Islamic law as a complete and total system (syar"at Islam secara kaffah)."28

On one level, such appeals to Islamic law, and the role of the state in implementing its social vision echo the broad appeal of Sharìa as an abstract, ideal vision of justice and social order increasingly popular across Muslim Indonesia over the past decade. Indeed, to a significant degree it may be said that the implementation of Islamic law in Aceh as part of its 'Special Autonomy' status has served to bring Acehnese understandings and practices of Islam more firmly in line with Indonesian national standards than at any time in its previous history. This has become evident not only in the convergence of Islamic discourses between Aceh and Jakarta, but also in the recent proliferation of branches of Indonesian Islamic organizations across the province. For most of Aceh's history, the major national Muslim organizations, including the NU and Muhammadiyah, had little success in Aceh. Since the peace, however, these and other Indonesian national organizations have grown in the province. Likewise models of Islamic education developed in Java and elsewhere in Indonesia have been making inroads in Aceh, including the influential network of Gontor 'modern pesantren' that opened a campus in Aceh in 2008. ${ }^{29}$ These developments have been facilitated by the work of the new and newly reconstituted state Islamic institutions of Aceh's contemporary Islamic legal system.

26 BRR, Religion, Social Culture: Revitalizing the Dignity of Society (Jakarta: Multi Donor Fund/ UNDP, 2009), 20.

27 Regulation of the President of Republic of Indonesia Number 30 Year 2005 on Master Plan for Rehabilitation and Reconstruction for the Regions and People of the Province of Nanggroe Aceh Darussalam and Nias Islands of the Province of North Sumatra-Main Book of Rehabilitation and Reconstruction (Jakarta: 2005), IV4.

28 the 'Forum Silaturrahmi Ulama Perempuan se-Nanggroe Aceh Darussalam' was held at the Hermes Palace Hotel and sponsored by Mitra Sejati Perempuan Indonesia. See Siti Zalikha Ibrahim, "Santri Menemukan Jati Diri," in Menuju Syariat Islam Kaffah: Pikirandan Pengalaman Santri Aceh dalam menuntut Ilmu dan Hubungannya dengan Perbuatan Nyata, ed. Ahmadun Yosi Herfanda (Banda Aceh: Lepena, 2008), 27-80, 74 .

29 “Pondok Modern Darul Amin Gontor 10-Meunasah Baro, Seulimeum, Aceh Besar," Wardun: Warta Dunia Pondok Modern Darussalam Gontor 61 (Sha'bān 1429): 98-100. 


\section{Constructing a New 'Sharīa System'}

Beyond the integration of Acehnese Islam into broader Indonesian national standards, state projects for the implementation of Shari'a in Aceh have been seen as useful for building a bulwark against the kind of NGO-style 'globalization' that was feared by both Acehnese "ulamā and the Indonesian central government. Jakarta based Islamist activists and conspiracy theorists actively promoted the idea that post tsunami reconstruction programs had opened the floodgates for Christian missionaries and Zionist agents attempting to turn the Acehnese away from the true path of Islam. ${ }^{30}$ At the same time within Aceh itself, Muslim intellectuals from the State Institute of Islamic Studies (IAIN) were working to develop new strategies to counter what some there perceived to be a threat of invasion by anti Islamic forces from the West. Their efforts included the development of new da'wa media and education programs to instill their vision of proper Islamic morality upon the populace. ${ }^{31}$ Other governmental institutions also mobilized in the name of Sharīa as a response to perceived foreign corruption in more physically assertive ways.33 Shar'’a was seen as having the potential both to protect Aceh and to facilitate its integration into Indonesian national culture, including its own particular experiences of Islamic revival. The state's coercive apparatus put into place in service of the Shari'a was used not only as a counter to the deleterious cultural effects of globalization, but also to steer social development in desired directions.

Like the BRR, the World Bank, and other stakeholders in Aceh's post tsunami reconstruction, the ideological supporters of the new Sharì'a system saw tremendous opportunities to transform society in the wake of the great wave. The vision of the main architects of this system has been a thoroughly forward looking one, and the first head of the State Shari'a Agency, Al Yasa Abubakar, made a point of repeatedly arguing that "Acehnese society does not want, and will not try, to turn back the clock." ${ }^{32}$ Rather, the ideology of many advocates of Sharī'a implementation in contemporary Aceh is one with a vision of future oriented social transformation, insisting on the need to move beyond 'traditional' understandings toward a vision of Islam that actively engages with modern developments in fields including education, economics and medicine. ${ }^{33}$ The goal is to use the new Islamic legal system to bring about sweeping social change in both the regulation of society and the character of individual Muslims to conform to a particular set of modern ideals. Al Yasa himself lists first among his expressed goals of Sharī'a implementation in Aceh

30 See, for example, Rizki Ridyasmara, Gerilya Salib di Serambi Mekkah: Dari ZamanPortugis Hingga Paska Tsunami (Jakarta: Pustaka Al-Kautsar, 2006).

31 Muhammad A.R., Potret Aceh Pasca Tsunami: Mengintip Peran Dayah dalam MenghadapiAkulturasi Akhlak (Aceh: Ar-Raniry Press, 2007), 83-114. For example, in August, 2006 the Sharīa police (WH) forced their way into the UN compound in Banda Aceh and attempted to inspect staff bedrooms there. Fadlullah Wilmot, "Sharīah in Aceh: Panacea or Blight?" Accord: An International Review of Peace Initiatives20 (2008): 77-8.

32 Al Yasa Abubakar, Syari" at Islam di Provinsi Nanggroe Aceh Darussalam: Paradigma,Kebijakan, dan Kegiatan (Banda Aceh: Dinas Syariat Islam NAD, 2008), 81. Indeed evenwhen at times the past glories of the Acehnese sultanate during its seventeenth-century 'golden age' are rhetorically evoked, it is clear that returning to a pre-modern model of Islamic law is not the primary motivation of the majority of people involved with the current experiment in establishing a Sharì'a system in Aceh.

33 ibid., 25. 
that of improving and perfecting the Islam of individual Muslims, arguing that if this is accomplished, the Acehnese as a whole will become more "honest, frugal, studious, diligent, loyal, intelligent, and emotionally mature." ${ }^{34}$

The model of Muslim revivalist ideology that animates contemporary agendas of Sharīa implementation in Aceh is one that not only reflects, but in some sense actually prefigures, broader Indonesian national trends of Islamization over the past four decades. These developments are often subsumed under the general rubric of da'wa. The first college Faculty of Da'wa established anywhere in Indonesia was at the State Institute for Islamic Studies (IAIN) at Banda Aceh in 1964..$^{35}$ This innovation in Islamic higher education was vigorously promoted by Aceh's former governor, Ali Hasjmy (d. 1998), who played a key role in promoting this vision of Islam as a means of reconciling local concerns for religious identity with the political and economic agendas of the Indonesian nation state. ${ }^{36}$ Elsewhere in Indonesia, the da'wa movement was accelerated through the activities of campus based Islamist organizations, the most prominent of which was the Salman Mosque Movement on the campus of the Bandung Institute of Technology (ITB).$^{37}$ Its aim was to implant reformed 'Islamic values' into the developing minds of future Indonesian technocrats by transforming individuals through the careful regulation of ritual practice, personal morality, and the promotion of Islamic public symbols of Islam, including in many cases the adoption of forms of 'Islamic dress' such as the head scarf ( jilbab) for women. ${ }^{38}$

Although the students associated with the Salman Mosque movement looked broadly to contemporary developments in the Middle East for inspiration, particularly prominent influence came from neo Ikhwani forms of activism that developed during the 1970s. ${ }^{39}$ This largely depoliticized emphasis on reinvigorating Islam as a system of personalized devotionalism and public moralism was, nonetheless, embedded within a totalizing vision of Islam as a systematized way of life. ${ }^{40}$ By the end of the twentieth century,

34 ibid., 81-5.

35 Risalah Fakultas Dakwah dan Publisistik I.A.I.N Djami'ah Ar-Raniry Darussalam (BandaAceh: Bahagian Publikasi Fakultas Dakwah/Publisistik Darussalam, 1969), 18.

36 Hasjmy produced countless public statements on this modern vision of da'wa, ranging from book-length publications to public addresses. See, for example: A. Hasjmy, DusturDa'wa Menurut Al Qurän (Jakarta: Bulan Bintang, 1974); “Peranan Da’wa Islamiyah dalamPembangunan Masyarakat Desa," speech read at an Aceh Ulama Council workshop held at Banda Aceh on 13 December, 1977 (Collection of the Ali Hasjmy Foundation Library, Banda Aceh). On the broader nexus between da'wa and developmentalism in Indonesia under Suharto's New Order, see R. Michael Feener, Muslim Legal ought in ModernIndonesia (Cambridge: Cambridge University Press, 2007), 103-9.

37 "Gerakan Kaum Muda Islam Mesjid Salman," in Gerakan Islam Kontemporer diIndonesia, ed. Abdul Aziz, Imam olkhah, and Soetarman S. (Jakarta: Pustaka Firdaus,1989). See also Chaider S. Bamualim, Islamization and Resistance: A Study of Religions, Stateand Society in Western Java c. 1965 (forthcoming).

38 A compilation of influential sermons delivered at ITB's Salman Mosque stresses these points. On these, see Muhammad Imaduddin Abdul Rahim, Kuliah Tauhid (Bandung: Pustaka-Perpustakaan Salman ITB, 1980), 117-29, et passim.

39 Following the strong measures of the Egyptian government to suppress the Ikhwan al-Muslimin (Muslim Brotherhood) in the 1950s and 1960s, a new model of social engagement emerged from the movement, emphasizing education and da"wa, rather than direct contestation over control of the state. See Meir Hatina, "Restoring a Lost Identity: Models of Education in Modern Islamic Thought," British Journal of Middle Eastern Studies33:2 (2006): 182-4; Barbara H.E. Zollner, e Muslim Brotherhood: Hasan al-Hudaybi andIdeology (Abingdon: Routledge, 2009).

${ }_{40}$ Rifki Rosyad, A Quest for True Islam: A Study of the Islamic Resurgence Movement amongthe 
such visions of Islam as a totalizing system (nizam ) came to be increasingly described by the phrase 'Islam yang kaffah.' This same phrase has emerged as a prominent trope in Islamist discourses in Aceh, where it was integrated into official government publications and the language of the legislation that established the province's new Islamic legal system. ${ }^{41}$

The degree to which the transformation of visions of Islam in Aceh has been linked to broader Indonesian national trends is explicitly emphasized in the official text of the 'Clarification' (Penjelasan) of Qanun 11/2002.42 There it is asserted that, following the fall of Suharto in 1998, unprecedented possibilities were opened for the application of Islamic law in the country. Governmental decentralization policies introduced at that time facilitated the promulgation of 'Sharia based' regional laws (perda syariat) by dozens of local governments across the archipelago. ${ }^{43}$ In Aceh, however, moves in this direction were allowed to proceed further than anywhere else after the province was granted the authority to formally implement Islamic law by Law No. 44/1999 on the 'Special Status of the Province of Aceh Special Region'.

The provincial government of Aceh enthusiastically took to this new authority over the administration of religion in its 2001 five year plan for Aceh, which pronounced as its primary aim the $d a^{\prime} w a$ ideal of creating a society based on Islam in which the Sharì'a would be applied in its totality (secara kaffah) across all aspects of social life. ${ }^{44}$ However during the first five years of Aceh's special autonomy very little was accomplished in terms of the formal implementation of Islamic law in the province. The situation began to change dramatically in the wake of the December 2004 tsunami, at which time a heightened level of religious enthusiasm, combined with a new sense of rebuilding Aceh, empowered the expansion and development of the Islamic legal system. Over the years that followed, Muslim intellectuals in Aceh were generally eager to recognize and reinforce the government's use of the institutional structures of state Sharì'a to promote social transformation. As a prominent lecturer in the philosophy of law at Banda Aceh's IAIN has emphatically expressed it, "The Sharī'a must be systematized to order every action of a Muslim's life... There is not a single dimension of Muslim life that can escape being ordered by the Shar ì'a." ${ }^{45}$ In this totalizing rhetoric, Sharīa has come increasingly to serve as the idiom in which sweeping transformations of Acehnese society are elaborated.

Youth in Bandung, Indonesia (Canberra: Australian National University Press, 2007),17.

${ }_{41}$ I have described the ideological genealogies of these discourses more extensively in: "Syiar Islam' in Contemporary Aceh," paper presented at the European Association for Southeast Asian Studies Conference (Naples, September 2007).

42 "Penjelasan atas Qanun Provinsi Nanggroe Aceh Darussalam Nomor 11 Tahun 2002 tentang Pelaksanaan Syari'at Islam Bidang Aqidah, Ibadah, dan Syi'ar Islam," HimpunanPeraturan Perundang Undangan tentang Mahkamah Syar"iyah di Provinsi Nanggroe Aceh Darussalam (Banda Aceh: Mahkamah Syar'iyah Propinsi NAD, 2006), 201-9.

43 Robin Bush, "Regional Sharia Regulations in Indonesia: Anomaly or Symptom?” in Expressing Islam: Religious Life and Politics in Indonesia, ed. Greg Fealy and Sally White(Singapore: Institute of Southeast Asian Studies, 2008), 174-91.

44 Al Yasa Abubakar, “Rencana Strategis Provinsi NAD Tahun 2001-2005," in BungaRampai Pelaksanaan Syariat Islam: Pendukung Qanun Pelaksanaan Syariat Islam, (BandaAceh: Dinas Syariat Islam Aceh, 2009), 20.

45 Syahrizal, "Strategi Pelaksanaan Syari'at Islam di Nanggroe Aceh Darussalam," in SuaraKhatib Baiturrahman, ed. Azman Ismail (Banda Aceh: Pengurus Masjid Raya Baiturrahman,2006), 21. 


\section{VI.'Living Law'}

The work of developing and promoting the Islamization of law in Aceh was to a great extent carried out by academics at the National Institute for Islamic Studies (IAIN) campus in Banda Aceh. Many of the most prominent figures involved in these developments were also graduates of al -Azhar, where they had been exposed to neo-Ikhwani understandings of Islamic law and the religious dimensions of social change as expressed in works like al-Hu(aybï's Du"āt lāQu'àt ${ }^{46}$ In their later careers back in Aceh, their work of recasting such visions of Islamic law to bring them more in line with both Indonesian discourses about law as a tool of development, and the international rhetoric of post disaster recovery, demonstrates the dramatic ways in which discourses on law and society in Indonesia have changed over the past half century. At the same time, I would argue, it also signals the need to pay careful attention to the complex impact that non-Muslim discourses on law and social development may have on contemporary formulations and interpretations of Sharìa.

For example, Syahrizal has urged the Acehnese to seize the opportunity that had been provided by the 'Special Autonomy' laws to "establish Islamic law as the 'living law' in Aceh" ${ }^{\text {"47 }}$ This particular form for expressing the desired goal of the new Islamic legal system engages with some of the most central aspects of legal thought debated among Indonesian jurists since the founding of the independent nation in 1945. In particular it reflects the major shift in emphasis from understandings of law as a reflection of empirical social fact to law as a system for the normative prescription of ideal values.

'Living law' has long been the main rubric under which the Indonesian state has effected significant changes to the legal culture of the nation. In the early years of independence, mapping 'the living law' of the country came to define the primary battleground for those arguing diverse positions across an increasingly wide gap between proponents of adat and proponents of Islam as sources for national law ${ }^{48}$ The centrality of the concept of 'living law' in Indonesian legal thought had its origins in the field of adat (customary law) studies in the Dutch colonial period. The early development of the field of adat law and its rise to prominence in discourses on law and administration in the Netherlands East Indies were driven by the work of Cornelius van Vollenhoven ${ }^{49}$ In elaborating his influential model of adat law, van Vollenhoven developed conceptions of 'living law' and legal pluralism that in many ways paralleled those of his Austrian contemporary Eugen Ehrlich, who summed up his Grundlegung der Soziologie des Rechts on the sociology of law with the

46 For example, Al Yasa Abubakar, the founding director of Aceh's State Sharīa Agency (Dinas Syariat Islam) has taken a master's degree in u(ūl al-fiqh from al-Azhar in 1980, and Muslim Ibrahim, Head of Aceh's Ulama Council (Majelis Permusyawaratan Ulama), spent over a decade at al-Azhar as well (19731984), taking graduate degrees in tarbiya and fiqh.

47 Syahrizal, ed., Kontekstualisasi Syari"at Islam di Nanggroe Aceh Darussalam (Banda Aceh: ArRaniry Press, 2003), xvi.

48 Ratno Lukito, "Law and Politics in Post-Independence Indonesia: A Case Study of Religious and Adat Courts," in Sharī”a and Politics in Modern Indonesia, ed. Arskal Salim and Azyumardi Azra (Singapore: Institute of Southeast Asian Studies Press, 2003), 21.

49 On these developments, see further Roy Ellen, " e Development of Anthropology and Colonial Policy in the Netherlands: 1800-1960," Journal of the History of the BehavioralSciences 12 (1976): 303-24; C. Fasseur, De Indologen: Ambtenaren voor de Oost, 1825-1950(Amsterdam: Bert Bakker, 1993); and Peter J. Burns, e Leiden Legacy: Concepts of Lawin Indonesia (Jakarta: PT Pradnya Paramita, 1999), 246-54. 
sentence, "At the present as well as at any other time, the center of gravity of legal development lies not in legislation, nor in juristic science, nor in judicial decision, but in society itself." ${ }^{50}$ Ehrlich is commonly regarded as a founding figure in the sociology of law for his attempts at recasting the scope within which jurists work to include broader considerations-calling for lawyers to be trained in sociology, economics and even psychology in addition to their legal studies ${ }^{51}$ As will be discussed below, such an expansive view of the social dimension of legal change is something that is frequently echoed in the writings and everyday language of many of those directly involved with the design and operation of Aceh's Islamic legal system.

\section{Legal Instrumentalism and The Technocrats}

Over the course of its long career and development out of Dutch adat law discussions, the Indonesian concept of 'living law' (Ind. hukumyang hidup) mutated in terms of its relative emphasis: from ethnographic description to ideological prescription. Adat law came to play a powerful symbolic role in the Indonesian nationalist movement, and as such was integrated into the modernizing reform projects of Dutch trained scholars like R. Soepomo, who was an influential figure in the drafting of independent Indonesia's first Constitution..$^{52}$ In the process, the nostalgic idealism of 'custom' faded under the glare of various shades of revolutionary romanticism. As the von BendaBeckmanns have recently summarized these developments, "Living law here functioned as a legitimation of a kind of Freie Rechtslehre" in a way that became clearly contrary to the visions of 'living law' advanced by van Vollenhoven and Ehrlich. ${ }^{53}$

These changes were deeply lamented by latter day exponents of clas sical adat law, including Mohamad Koesnoe, ${ }^{54}$ who argued that the foundation of the 1945 constitution-as outlined in the preamble- was fundamentally a 'metaphysical' conception of law manifest in 'nor mative principles.' ${ }^{55}$ The

50 Eugen Ehrlich, Fundamental Principles of the Sociology of Law (Cambridge, MA: Harvard University Press, 1936), xv.

51 Baudouin Dupret has compared Ehrlich's approach to that of Malinowski, with a shared emphasis on the ways in which cultural ideals govern human interaction to produce a 'law' that reflects norms of social control: Baudouin Dupret, "What is Plural in the Law? A Praxiological Answer," Égypte/Monde arabe, Troisième série, 1 (2005). http://ema.revues. org/index1869.html. Accessed November 4, 2010. e followers of van Vollenhoven, however, proved increasingly more amenable to lending their work on aspects of Indonesian society to the service of the courts and various branches of governmental administration. See Raymond Kennedy, "Applied Anthropology in the Dutch East Indies," Transactions of the New York Academy of Sciences Series 2.6 (1944): 157-62. For more on Ehrlich in relationto Dutch and Indonesian formulations of living law, see Franz and Keebet von Benda-Beckmann, " e Social Life of Living Law in Indonesia," in Living Law: ReconsideringEugen Ehrlich, ed. Marc Hertogh (Oxford: Hart Publishing, 2009).

52 Ab Massier, e Voice of the Law in Transition: Indonesian Jurists and their Languages,1915-2000 (Leiden: KITLV Press, 2008), 151.

53 von Benda-Beckmann, “ e Social Life of Living Law in Indonesia," 187.

54 Moh. Koesnoe, "Mengamati Konsep Hukum di Dalam Masyarakat Kita," in KapitaSelekta Hukum Adat: Suatu Pemikiran Baru, ed. M. Ali Boediarto (Jakarta: Varia Peradilan-Ikatan Hakim Indonesia, 2002), 53-82.

55 In his discussion, Koesnoe references the work of Roscoe Pound on law as a 'tool of social engineering' - something that he sees as facilitating the further deterioration of law to the point that "it functions as a political manifesto by the powers that promulgated it." Koesnoe, "Mengamati Konsep Hukum," 58-71. 
movement away from this idealist toward a more instrumentalist vision of law over subsequent decades of Indone sian history was, in his view, a reflection of the influence of Marxist legal theory upon Soekarno's left-leaning government ${ }^{56}$ Even after the collapse of the regime in 1965, however, basic understandings of law in instrumentalist terms persisted and found new forms of expression from the New Order Indonesian state. In 1973 they re emerged in theMain Outlines of National Direction (GBHN) under the new idiom of 'law as a tool [for national development],' which Koesnoe glossed as "law as an instrument to facilitate the advance of political objectives ${ }^{\text {"57 }}$ By this point, law was no longer a descriptive reflection of the actual norms active in society, as professed by earlier proponents of adat law. Rather, law had come to be viewed as a means by which to define the ideals toward which society should be aspiring. This fundamental shift from description to prescription in dominant Indonesian philosophies of law allowed the state to legitimize its various agendas of restructuring and reform in a wide number of areas, including the articulation of official understandings of Islamic law as 'living fiqh,' as John Bowen has noted in relation to the 1991 Indonesian Compilation of IslamicLaws. ${ }^{58}$

Over the course of the New Order period (1965-1998), the Indo nesian government instituted an entire range of policies in which par ticular forms of Islamic law were pressed into the service of state projects for modernization and economic development. These programs were pursued across the full spectrum of Islamic orientations and insti tutions, but particular efforts were made to engage with the formal structures of rural pesantren and village leadership. These structures were mobilized and prominent "ulamā were recruited to produce Islamic justifications for government initiatives in what proved to be a very successful promotion of Indonesia's family planning program in the 1970s. ${ }^{59}$

While such piecemeal reforms were accommodated to traditionalist Muslim social structures of authority, Islamic modernists and revivalists were open to ideas of even more comprehensive social transformation. The modern idea of Islamic law as a totalizing system had been known in Aceh since the mid twentieth century and was promoted by the leader of the Darul Islam insurgency. As early as 1962, Daud Beureueh used the term nizam in the sense of "rules that can order human life on all levels-individual, communal, societal, and governmental, as well as in international relations." ${ }^{60}$ This grand

56 Koesnoe, "Mengamati Konsep Hukum," 70. In particular there is a clear aversion to the 'legal nihilism' of Marxist legal philosophers in the line of Evgeny Pashukanis, which provided "a rationale for extraordinary state action... if the conscious plan for reshaping society so demanded.” Peter C. Caldwell, Dictatorship, State Planning, and Social eory inthe German Democratic Republic (Cambridge University Press, 2003), 61.

57 Koesnoe, "Mengamati Konsep Hukum," 62.

58 John R. Bowen, Islam, Law and Equality in Indonesia: An Anthropology of PublicReasoning (Cambridge, 2003), 190-2. For more on these developments, see Moch. NurIchwan, Official Reform of Islam: State Islam and the Ministry of Religious Affairs inContemporary Indonesia, 1966-2004 (Leiden University dissertation, 2006), 127-35.

59 See, for example, Ali Yafie, "Doktrin Fiqh dalam Program Kependudukan," in TeologiSosial: Telaah Kritis Persoalan Agama dan Kemanusiaan (Yogyakarta: LKPSM, 1997), 29-40.

60 “Muqaddimah Pelaksanaan Unsur-unsur Sjari'at Islam-9 April, 1962," in Analiansyah \& Jamhuri, Syariat Islam Di Nanggroe Aceh Darussalam: Inventarisasi Dokumen (Banda Aceh: Dinas Syariat Islam Provinsi Nanggroe Aceh Darussalam, 2008), 95. 
goal was never realized under the Acehnese movement for the establishment of an Islamic state. Fol lowing the defeat of the Darul Islam in the 1960s, however, the Indo nesian government came to appeal to Islamic norms to help promote its own range of development programs in Aceh.

The Indonesian administration of Aceh in the post-Darul Islam period was dominated by the modernizing agendas of economists and other secular trained experts who have come to be collectively referred to as "technocrats." In the 1970s, John McDougal characterized their "ideology of modernity" as "mental enlightenment via material progress." ${ }^{1}$ Stuart Schlegel has described the situation as that of a tech nocratic civil government pushing for economic development in Banda Aceh, surrounded by "a sea of traditional peasant villagers" in which the ulamā' remained "the major rural political force." 62 These two worlds, moreover, were characterized by very different visions of mod ern social change:

Development for the government officials and the academics means that technocratic advance is the proper course of historical change. What a mod ernist modern Muslim ulama [sic] means by development is something quite different and he may want no part of economic and secular change. For the ulama and most village people of all streams, development indeed meanssuch things as improved medical treatment, but primarily it means better mosques, a wider literacy in Arabic, and more people familiar with the Koran. ${ }^{63}$

In his presentation of the ways in which these diverse worlds interacted, Schlegel presented sketches of two prominent Acehnese technocrats of the late 1970s: one "typical of modernizing elite figures in most of the world" at that time-materialist, pragmatist, secularist, and aggressively flouting religious norms and traditional culture-and the other a 'pious' technocrat who displayed a commitment to normative Islamic belief and practice as popularly understood in Aceh. He concluded that the predominance of the latter type of technocrat in Aceh was responsible for "their tentative acceptance by Acehnese society at large because they share in the public symbols of its unity." ${ }^{44}$ Schlegel presents these pious technocrats as representative of what he termed 'Golkar Islam' ${ }^{65}$ in a way that marks them as a rather curious exception to broader trends in the 1970s-or so it appeared at the time. With the advantage of his torical hindsight, however, his remarks seem prescient as an early man ifestation of a trend that developed significantly over the two decades that followed-that of increasing numbers of observant Muslims estab lishing themselves within the structures of the Indonesian state.66

By the 1990s there was clearly an increasing convergence between the

61 John McDougal, “ e Technocrat's Ideology of Modernity," in What is ModernIndonesian Culture?, ed. Gloria Davis (Athens: Ohio University Center for InternationalStudies, 1979), 156.

62 Stuart A. Schlegel, "Technocrats in a Muslim Society: Symbolic Community in Aceh," in What is Modern Indonesian Culture?, ed. Gloria Davis (Athens: Ohio University Center for International Studies, 1979), 237.

63 ibid., 244.

64 ibid., 245

65 The reference is to the government's political organization, which all Indonesian civil servants had to join in lieu of political party membership under Suharto's New Order (1965-1998).

66 these developments were signalled in a significant way with the establishment of the Association of Indonesian Muslim Intellectuals (ICMI) in 1990. See Robert W. Hefner, "Islam, State, and Civil Society: ICMI and the Struggle for the Indonesian Middle Class," Indonesia 56 (1993): 1-35. 
goals and orientations of 'secular' and self consciously 'Islamic' technocrats in Indonesia. As early as the 1970s, however, McDougal had noted the penchant of secular technocrats not only to emphasize the importance of clearly structured organizations, but also their 'puri tanical' anxieties about the perceived weakening of moral norms in modern society. ${ }^{67}$ Both of these are characteristics shared with the class of upwardly mobile Islamic revivalists of more recent decades. Indeed even the kind of 'mental and cultural enlightenment' of the more secu lar economists and engineers espoused many of the same values that were later listed by the architects of Aceh's new Islamic legal system as desirable outcomes of Sharī'a discipline. ${ }^{68}$ Both groups thus aimed not only for the technical implementation of particular developmentalist policies, but also the cultivation of particular kinds of subjectivities as the foundation for successful programs of modernization.

\section{Modern Transformations of Muslim Jurisprudence}

At work in all this are new configurations of law, moral authority, and state power reflecting the global order of modern nations. Such trans formations of Islamic law are by no means novel to the Acehnese case. Wael Hallaq has noted that in the classical period the Shari'a pre supposed and was dependent upon a 'moral community' manifest in myriad informal structures. ${ }^{69}$ In the absence of a sense of moral com munity in the modern period, such a notion of moral community was replaced with the more systematic and bureaucratic institutions of the state. Oussama Arabi has commented on the ways in which the formal ization of Islamic law under Ottoman reforms presented a drastic shift from a fundamentally religious and theological conception of law to an instrumentalist, political conception, in which, "to an unprecedented degree, Sharī'a became a positive tool, a leverage at the service of state interests." 70 Through these modernizing transformations there has been a marked shift in the relative emphasis on social maintenance vis-à-vis social engineering in dominant conceptions of Islamic law.

These developments were facilitated by the ascendance of previously constrained modes of 'utilitarian' reasoning in Islamic Muslim juris prudence ${ }^{.71}$ Such approaches, framed in particular as they are by radi cally refashioned conceptions of 'necessities' ('arūriyyāt) and 'benefit' (ma(la+a), have assumed a prominent place in Muslim thought in the modern period under the influence of Rashīd $\operatorname{Ri}\left(\bar{a}\right.$ and other twentieth-century reformists ${ }^{72}$ The pervasive instrumentalism of this mode of modern Islamic reformism makes it eminently amenable to prescriptive agendas of law as social engineering. This general tone of instrumentalism in modern fiqh has been easily accommodated with

67 McDougal, “ e Technocrat's Ideology of Modernity," 156-7.

68 Al Yasa Abubakar, Syari” at Islam, 81-5.

69 Wael B. Hallaq, Sharı̄”a: eory, Practice, Transformations (New York: Cambridge University Press, 2009), 544.

70 Oussama Arabi, Studies in Modern Islamic Law and Jurisprudence( e Hague: Kluwer Law International, 2001), 192.

71 On the impact of the modern emergence of this line of Muslim legal thought in Egypt, see Clark B. Lombardi, State Law as Islamic Law in Modern Egypt: e Incorporation of theSharı̄”a into Egyptian Constitutional Law (Leiden: E.J. Brill, 2006), 38-40.

72 Wael B. Hallaq, A History of Islamic Legal eories (Cambridge University Press, 1997), 164-74, 219. 
other trends in non-Muslim jurisprudence that view law as a tool of social engineering. I would argue that viewing the implementation of Islamic law in contemporary Aceh as a project for social transforma tion-rather than merely as a series of reactive measures to the perceived 'crises of modernity' and/or political machinations of national and local elites-can provide a new perspective on why the Sharī'a system has taken its present shape, and the extent of its accomplishments and failures.

\section{Issues of Efficacy in Implementation}

In addressing the issue of the extent to which Islamic law changes behavior in modern Indonesia, Barry Hooker has proposed the follow ing standards for assessing their efficacy: (1) that they state criteria by which their validity can be tested, (2) that they must be capable of effective implementation by public officials, and (3) that they must extract a basic level of compliance from the population. In Hooker's assessment of the situation in 2008, the Acehnese Qanun had failed these tests ${ }^{73}$ It is hard to argue otherwise. Indeed, on nearly every indicator that one might use to evaluate the success of their attempts at creating a new legal order, the results are less than impressive. Well beyond Hooker's criteria, Aceh's Sharì'a system appears to have fallen short on key indices, such as its effectiveness in building new institu tions, public confidence in the formal apparatus of the legal system, and an actual impact on crime rates.

Cases involving gambling, alcohol consumption and khalwat have never, to date, amounted to a significant portion of the caseload of Aceh's Sharì' a Courts. Since 2007, there has been a marked decrease in the number of cases involving infractions of Sharī'a with regard to sexual morality, gambling and alcohol brought to court across the prov ince ${ }^{.74}$ In general, Aceh's Sharī' a Courts continue to follow patterns well attested at the national level, and in terms of their actual day-to-day operation, they appear to be little different from Islamic Courts in other Indonesian provinces ${ }^{75}$ Other offices in Aceh's Islamic legal system have likewise little distinguished themselves over recent years. Given such a performance record in the sphere of formal legal institutions, there are legitimate questions as to what, exactly, has been accomplished by a decade of Sharī'a implementation in Aceh.

The project of Sharī'a implementation is frequently characterized as disappointing by many local proponents of the system itself ${ }^{76}$ its apparent failure to deliver tangible results in the formal legal sphere, Sharī'a nevertheless remains a defining referent at the center of discus sions on law and society in Aceh. Here the importance of the project for developments beyond the areas of legislation and official govern mental institutions becomes clear. As one prominent Acehnese sup porter of the Sharīa system has expressed it:

73 M.B. Hooker, Indonesian Syariah: Defining a National School of Islamic Law (Singapore: ISEAS, 2008), 292.

74 Statistics compiled by Muhammad Yusuf, Panitera/Sekretaris Mahkamah Syari'yah Aceh, 5 June 2009.

75 The vast majority of the cases before the court continue to be related to divorce, followed in number by inheritance-and these cases are generally decided according to rules and norms commonly found in the decisions of religious courts elsewhere in Indonesia.

${ }^{76}$ Part of this is connected to a perceived 'lack of political will' to enforce Sharī'a on the part of Irwandi Yusuf, a former member of the Free Aceh Movement who was elected as Aceh's governor in 2007. 
The success of Sharì a implementation is not measured solely by the number of cases decided by the courts or the extent to which the sentences they pronounce are formally executed. Rather the indication of success should be found in the decrease of violations of the Sharì a, and in the heightened awareness of the need to uphold the law of God as a protector and as a bearer of benefits for individuals, families and society. ${ }^{77}$

The role of Sharì'a emphasized here as a means of heightening aware ness (kesadaran) and providing broadly conceived 'benefit' (kemasla hatan ) for society clearly points to the way in which developments inAceh have had effects well beyond the limits of blackletter law and the particular policy enactments of formal state institutions. The imple mentation of Islamic law in Aceh has thus been a project not just-or I would argue, even primarilyone of legal change sensu stricto, but rather one aiming at far broader social transformations.

In my forthcoming monograph on Aceh's contemporary Islamic legal system, I present detailed analyses of the institutional structures and everyday operations of the Ulama Council (MPU), the State Sharīa Agency (DSI), the Sharı'a Police (WH), and the Sharīa Courts. ${ }^{78}$ My work in Aceh started five years ago with an eye to providing an empir ically-grounded study of a contemporary system for the actual applica tion of Islamic law. As I spent increasing amounts of time at the offices and in the field with people directly involved, I struggled to understand why, despite the proliferation of offices and increased staffing, Aceh's state Sharī' a institutions appeared not to be doing very much law. The MPU, for example, dedicates only a small fraction of its time and resources to working on draft legislation; the DSI is little involved in administering positive law, WH patrols rarely if ever result in formal arrests, and consequently only a small number of jināya cases come before the Sharīa courts each year. Through studies of these develop ments it has become clear that the new state structures established for the implementation of Sharìa have generally made their most signifi cant impacts outside of the formal legal sphere.

\section{Social Engineering}

Social engineering and related terms in various European languages (sociale ingenieurs in Dutch, social ingenjörskonst in Swedish, etc.) have carried diverse progressive and pejorative connotations in different circles over the past century. Carl Macklund has referred to social engi neering as an important aspect of modernity that can and should be approached in diverse ways, depending on particular contexts, as "uto pian ideology, as a set of paternalistic-cum-scientistic practices in oper ation, as a metaphor of state authority, and as a rhetorical strategy within American industrial betterment and scientific management" 79 In some cases the term 'social engineering' has been deployed with reference to an "antipolitics" intended to circumvent

\footnotetext{
Syahrizal, "Strategi Pelaksanaan Syari'at Islam," 20-5.

Feener, Sharī”a as Social Engineering.

79 Carl Marklund, "Adjusting Facts and Values-Reconciling Politics with Science: Some notes on the Rhetorics of Social Engineering in Depression-Era Sweden and the USA," Ideas in History II:2 (2007): 10 .
} 
the failings of popular democracy, ${ }^{80}$ and as a 'rhetorical tool' implying strategies by which subject populations could be manipulated "in such a way that they came to "love their servitude."'81 Karl Popper vehemently critiqued what he referred to as 'Utopian social engineering' as 'most dangerous' for its "uncompromising radicalism,"82 and today the term 'social engi neering' is associated by some with the pursuit of "lethal utopias" in Nazi Germany and Stalin's Soviet Union ${ }^{83}$

These negative glosses on social engineering are largely reactions to the tragic historical trajectories of mid twentieth-century Europe. How-ever such a myopic view of the concept can obscure important aspects of its earlier usage that were combined with idealistic agendas for the betterment of both communities and individual human lives. The ear liest noted reference to 'social engineers' (in the writings of the radical Dutch industrialist J.C. van Marken) emphasized the development of technical expertise in the "management" of "specifically human problems." ${ }^{84}$ The influential Swedish academic Gunnar Myrdal explic itly introduced the values of "modern social democratic political ambitions" ${ }^{85}$ to determine the direction of social engineering, pro claiming (in 1944), "We have today in social science a greater trust in the improvability of man and society than we have ever had since the Enlightenment." noted, however, that the tone of social engineering agendas was not exclusively secular, particularly in the United States, where in the early twentieth century a number of would be social engineers also figured as 'socioreligious uplifters' with support from 'Christian Sociologists' such as Edwin Earp ${ }^{87}$ and links to the Social Gospel movement through figures such as Pastor Josiah Strong. ${ }^{88}$

More specific conceptions of law as social engineering have their own complex history in modern Western thought, ranging across discussions of political ideology, policy planning, and jurisprudence. The broad scope of these discussions parallel in a provocative way contemporary discourses on Sharìa among reform minded Muslims in Aceh and elsewhere. In both cases, discussions of rules, norms and social change extend well beyond the limits of blackletter law and formal legal institutions.

In his introduction to the English translation of Ehrlich's magnum opus

80 John M. Jordan, Machine-Age Ideology: Social Engineering and American Liberalism,1911-1939 (Chapel Hill, NC: University of North Carolina Press, 1994).

81 David Östlund, "A Knower and Friend of Human Beings, Not Machines: e Business Career of the Terminology of Social Engineering, 1894-1910," Ideas in History II:2 (2007): 48.

82 Popper does, however, accept a more limited model of what he termed "piecemeal engineering" to deal with specific points of social policy. See Karl Popper, e Open Societyand Its Enemies: Volume One- e Spell of Plato (New York: Routledge, 2008-originallypublished, 1945), 166-7, 174.

83 Christopher R. Browning and Lewis H. Siegelbaum, "Frameworks for Social Engineering: Stalinist Schema of Identification and the Nazi Volksgemeinschaft," in Beyond Totalitarianism:Stalinism and Nazism Compared, ed. Michael Geyer and Sheila Fitzpatrick (CambridgeUniversity Press, 2009), 23165.

84 Östlund, "A Knower and a Friend," 66-74.

85 Johan Strang, “Overcoming the Rift Between 'is' and 'ought': Gunnar Myrdal and the Philosophy of Social Engineering," Ideas in History II:2 (2007): 144.

86 Gunnar Myrdal, An American Dilemma:e Negro Problem and Modern Democracy (New York: Harper and Brothers, 1944), 1023-4; cited in: Strang, "Overcoming the Rift," 186.

87 Edwin L. Earp, e Social Engineer (New York: Eaton and Mains, 1911).

${ }^{88}$ See Marklund, "Adjusting Facts and Values," 27-8; and Östlund, "A Knower and a Friend," 63-5, $79-80$. 
on the sociology of law, Roscoe Pound called attention to the importance of established relations of family and community in the production and maintenance of social order. ${ }^{89}$ Pound's own writings take into consideration diverse, overlapping types of 'interests' while also emphasizing the need for religion and conceptions of morality to support law's work in engineering the creation of a just society..$^{90}$ He maintained that well beyond dealing with breaches of particular legal rules, judicial and administrative processes "have a function of guidance as well," 91 and in fact saw legal history as the record of "a continually more efficacious social engineering." ${ }^{92}$ His conception of law in relation to social change was, however, far from radical, and might be better characterized as adaptive and realist, rather than idealistic and transformative. As one of his intellectual biographers has phrased it, conceptions of 'organicism' played a major role in limiting the degree to which Pound's vision of the sociology of law could be placed in the service of legal instrumentalism. ${ }^{93}$ Later assessments of Pound's jurisprudence have noted the great divergence between his views on law as social engineering and the uses to which his views were put by later jurists and philosophers. ${ }^{94}$

The term 'social engineering' in discussions of legal change appears to have been introduced into the Indonesian language through the translation of Pound's Introduction to the Philosophy of Law, which first appeared in 1963, and has been reprinted at least once every decade ever since. ${ }^{95}$ Over the intervening period, the term came to be used in Indonesian language texts to refer to more proactive programs of social development, thus coming to reflect the kind of legal instrumentalism to which Pound himself was distinctly opposed. However, there were also important continuities, particularly in the recognition of the importance of norms beyond legislation, where social engineering represented engagement with "that part of the whole field of social control which may be achieved by adjustment of human relations and ordering of human conduct through the action of politically organized society." ${ }^{\prime 6}$ It is in this context that we should approach the way in which the social engineering agenda of Aceh's contemporary Islamic legal system engages with the spheres of education and 'socialization'.

89 Roscoe Pound, “Introduction," in Ehrlich, Fundamental Principles, xxxiii.

90 Although this approach to law is mentioned in many of Pound's numerous articles, the most sustained treatment can be found in Roscoe Pound, Social Control through Law (New Haven: Yale University Press, 1942).

91 See, for example, Roscoe Pound, "Sociology of Law and Sociological Jurisprudence," The University of Toronto Law Journal 5:1 (1943): 15.

92 Roscoe Pound, An Introduction to the Philosophy of Law (New Haven: Yale University Press, 1955), 47.

93 Roscoe Pound, e Ideal Element in Law-Tagore Law Lectures, 1948 (Calcutta: Calcutta University Press, 1958), 179.

94 Edward B. McLean, Law and Civilization: e Legal ought of Roscoe Pound (Lanham, MD: University Press of America, 1992), 302-11.

95 I have had access to the 1982 edition, where the English language term 'social engineering' appears in the original, and is defined as: "applying law and sociological principles to reach particular, recognized social goals" (menerapkan hukum dan asas-asas sosiologi yang telah ditetapkan untuk mencapai tujuan sosial yang khusus dan diakui). RoscoePound, Pengantar Filsafat Hukum, diterjemahkan dari edisi yang diperluas oleh Drs. Mohamad Radjab (Jakarta: Bhratara Karya Aksara, 1982), 51.

96 David Wigdor, Roscoe Pound: Philosopher of Law (Westport, CT: Greenwood Press, 1974), 207-32. 


\section{XI.Education and Socialization}

The close connections between law, education and social order have a long and complex course of development in the histories of Muslim societies extending back to the classical period. ${ }^{97}$ During the nineteenth century, some Muslim rulers undertook new patterns of intervention into legal education that facilitated "fundamental and everlasting changes in the legal system."98 Since that time, new models of both law and education imported from the West had a transformative impact on the ways in which Muslims in many parts of the world came to understand Islam, the Sharīa, and the latter's function in society. ${ }^{99}$

With the revival of Islam on a global scale since the late twentieth century, there has been even broader engagement of educational programs in the service of redefining the role and interpretation of Islamic law in contemporary society. The social engineering aspects of the contemporary 'Islamic Trend' have been remarked upon by Gregory Starrett with particular reference to the function of state educational institutions in the process: "Having a captive audience, the school represents an ideal laboratory for social engineering, particularly if the knowledge imparted to children is taken home to their families."100 If this is true for day schools in Egypt, then all the more so for Aceh's traditional Islamic schools (dayah), which have been described by advocates of the Sharì'a system there as '24-hour laboratories for socialization. ${ }^{101}$

In Aceh, this goal has been pursued not only through the reform of formal educational institutions, but also in a wide range of other initiatives, including public outreach media campaigns and programs of popular preaching. ${ }^{102}$ Projects for the promotion of Sharìa through such means are generally referred to locally as sosialisasi . This Indonesian- language term, however, carries with it a range of meanings that may cause some confusion to those who read it exclusively in terms of its English cognate. Indeed the standard dictionary of contemporary Indonesian lists three separate definitions, ranging from the state seizure of private assets to the dissemination and publicizing of information. This latter definition is, in fact, perhaps the one that is most commonly encountered in many Indonesian discourses. There is, however, a third definition that refers to efforts to promote ideals so that they are understood and implemented. ${ }^{103}$ In this sense sosialisasi-in the sense of

97 See, for example, George Makdisi, "Hanbalite Islam," in Studies on Islam, ed. Merlin L. Swartz (Oxford University Press, 1981), 228-40; and Jonathan Berkey, e Transmissionof Knowledge in Medieval Cairo: A Social History of Islamic Education (Princeton UniversityPress, 1992).

98 Hallaq, Sharī"a, 135.

99 On the diverse transformative effects of modern styles of education in Muslim societies, see Dale Eickleman, Knowledge and Power in Morocco: e Education of a Twentieth CenturyNotable (Princeton: Princeton University Press, 1985); and the essays collected in RobertW. Hefner and Muhammad Qasim Zaman, ed., Schooling Islam: e Culture and Politicsof Modern Muslim Education (Princeton University Press, 2007). I have discussed the impactof modern educational reforms on Indonesian understandings of Islamic law in MuslimLegal ought in Modern Indonesia (Cambridge University Press, 2007).

100 Gregory Starrett, Putting Islam to Work: Education, Politics and Religious Transformation in Egypt (Berkeley: University of California Press, 1998), 116.

101 Hasbi Amiruddin, Menatap Masa Depan Dayah di Aceh (Banda Aceh: Yayasan Pena, 2008), 21.

102 See, for example, Muslim Ibrahim, Penahapan dalam Legislasi dan Penerapan Syari'atIslam (Jakarta: Cahaya Ilahi, 2006), 154.

103 Departemen Pendidikan Nasional, Kamus Besar Bahasa Indonesia Pusat Bahasa, EdisiKeempat (Jakarta: PT Gramedia Pustaka Utama, 2008), 1331-2. 
the habituating of individuals to behave according to socially-desired normsechoes its usage in developmental studies literature where socialization refers to "processes whereby naïve individuals are taught the skills, behavior patterns, values, and motivations needed for competent functioning in the culture."104

In contemporary Acehnese usage, there is considerable and constant slippage between these last two conceptions of sosialisasi. Indeed, its very vagueness seems to be one of the primary attractions, allowing for it to be used to describe activities ranging from public preaching programs to Sharīa Police (WH) spot inspections of women on the street whose clothes and head coverings do not fit official state definitions of proper Islamic dress.

Programs referred to locally in terms of sosialisasi are common activities across all of the Islamic legal institutions of Aceh-training, outreach, preaching and publication programs are being extensively pursued by the courts and the police force, as well as by the 'Ulamä' Council and the State Sharì'a Agency. The rhetoric of sosialisasi is so prevalent across the system that since 2007 it has become the most common framework of activity for most of Aceh's Islamic legal institutions. The contemporary usage of the term by officers of Aceh's Shari'a institutions, however, goes beyond the simple acquisition of existing norms and values to the deliberate promotion and implantation of aspirational standards of religious and moral rectitude aimed at facilitating the development of society as a whole in desired directions.

One important forum for the socialization of the Sharìa in Aceh is public preaching. As Barry Hooker has argued, the Friday sermon (khutba) is "one of the most public faces of Syariah" in contemporary Indonesia. ${ }^{105}$ One of the most popular topics of Friday sermons at the iconic Baiturrahman mosque in Banda Aceh is that of building a 'new generation' and building a just and prosperous and 'Islamic society.' 106 Such sentiments are echoed in the privately-produced newsletters and broadsheets commonly distributed at Friday prayers in Aceh by various groups advocating aggressive programs of devotionalism and moral policing that overlap and reinforce the agenda of the state Sharī'a system, while themselves remaining outside the formal spheres of government and party politics. ${ }^{107}$ The topics most frequently treated would fall under the broad rubrics of religious belief and practice (aqìda and ibādāt). These are areas that generally would be considered well beyond the sphere of positive law, properly speaking-but it would be a mistake to write these off as 'merely ritual' concerns, for they comprise important aspects of the all encompassing program of social transformation advocated by supporters of Aceh's contemporary Sharī'a system. ${ }^{108}$

104 Eleanor E. Maccoby, "Historical Overview of Socialization Research and eory," in Handbook of Socialization eory and Research, ed. Joan E. Grusec and Paul D. Hastings(New York: e Guilford Press, 2007), 13-41.

${ }^{105}$ Hooker, Indonesian Syariah, 129.

${ }^{106}$ See, for example, the sermons collected in Azman Ismail, ed., Suara Khatib Baitur-rahman (Banda Aceh: Pengurus Masjid Raya Baiturrahman, 2006).

107 Across Aceh on most Fridays one receives a free copy of broadsheets by various groups, depending upon which mosque one attends. Many of these are produced by Muslim groups based outside of Aceh, including Hizbut Tahrir, and the Pesantren al-Firqon al-Islami from Gresik (East Java).

108 As one prominent advocate of Aceh's Shari'a regime has put it, "e Shari'a is a perfect code of Islamic law governing all aspects of human behavior according the the Qur'an and the Sunna." Hasanuddin Yusuf Adan, Syari'at Islam di Aceh: Antara Implementasi danDiskriminasi (Banda Aceh: Adnin Foundation 
While studies of contemporary Islamic revivalism have increasingly emphasized the need to look beyond politics to appreciate the 'pedagogic realm' of modern Islamic discourse, there is a tendency to read da'wa education as a project of 'restoring' of 'cultural authenticity' and identity politics. ${ }^{109}$ These are undoubtedly important insights, but they can also distract us from other dimensions of contemporary Islamic agendas of education and socialization. Thus I would argue that in fact there is still a pervasive under appreciation of the ways in which modern Islamic education not only searches for roots, but also actively strives toward the future growth of new models of Muslim community.

The cultivation of new visions of Islam within the Acehnese community has impacts that are potentially more widely diffuse and enduring than the passing of any particular piece of legislation, or the establishment of any particular governmental agency. This is not to deny that there are other important factors involved here, including manipulations of elite politics at various levels. These, however, have already been extensively discussed by other observers of contemporary Aceh. What I would like to do with this work is something different - to open up some new space for a discussion of the contemporary experiment with Sharì'a implementation in Aceh that takes into account some of the broader religious and cultural developments that inform it.

The dominant model of Islam promoted by Aceh's Sharīa institutions bears a markedly revivalist character that attempts to transform the province through the implementation of a form of Islam believed to be complementary to modernizing aspirations of discipline, strength, and economic prosperity. One key feature of this reform agenda is the emphasis on 'purifying' Islamic belief and practice of corrupt and superstitious innovations. ${ }^{110}$ For some, the pursuit of this particular goal should be given priority over any concerns for more inclusive models of Islamic fraternity ( ukhuwwa), no matter how disruptive it may be in the short term. ${ }^{111}$ This radical remaking of Islamic Aceh is the ultimate goal of those who view the current system of implementing Islamic law as a form of social engineering. Their accomplishments to date, however, have been limited by a number of political and cultural factors. ${ }^{112}$

\section{Remaking Islamic Aceh}

While the imposition of formal Sharì'a legislation may have been an

Banda Aceh, 2008), 8.

109 See, for example, Hatina, "Restoring a Lost Identity," 196.

110 "Takhayul, Bid"ah dan Churafat" ('superstition, [blameworthy] innovation and fantasy')—an unholy trinity of wrongs commonly abbreviated as 'TBC' by modernist and revivalist Muslim reformers in Indonesia.

${ }^{111}$ For example, in one discussion at the State Islamic High School (STAIN), Lhokseumawe (22 May, 2008), one attending lecturer was sharply critical of those religious leaders who placed concerns for harmony and solidarity (ukhuwwa) ahead of the need to control deviant teachings-stressing the need for developing a model of higher education for a new generation of leaders who could realize this transformation once the older generation who are too set in their ways had died off.

112 I discuss these limiting factors in relation to various forms of Islamic belief and practice that have developed in directions different from those desired by the agents of Aceh's contemporary Sharìa system in "State Sharī"a and its Limits," paper prepared for the Islamin Contemporary Aceh: Reconfigurations of Ritual, Doctrine, Community and Authority workshop, Leiden University Centre for Islamic Studies, September 2011. 
"unwanted gift" imposed through a top down process initiated and manipulated by local and national political elites, ${ }^{113}$ the rhetorical and symbolic wrapping of the project has subsequently served to echo and amplify broader movements within contemporary Indonesian Islam for the transformation of society according to particular visions of Islamic reform. A central aspect of this is an emphasis on attempts to redefine local conceptions of Islam and its relation to Acehnese identity. The project of state Sharī' a may have made its initial appeals to a rather vague sense of 'Islam' as the essence of Acehnese culture and society (one rooted in 'traditionalist' practices and institutions), but in pursu ing its project of constructing a new Islamic legal system for the prov ince it has not only created new legislation and an extensive new bureaucracy, but also has worked to delimit the range of local under standings of 'Islam' to a particular stream of revivalist visions that has been gaining some degree of increasing acceptance across various sectors of society.

The contemporary Shari'a system in Aceh is deeply engaged in a project of shaping a modern Muslim subjectivity in tune with the key values of the developmentalist state, as evidenced by Aceh's Islamic legislation and the work of the State Sharì'a Agency. This transforma tion is elaborated within a framework that conceptualizes Islam in terms of an all encompassing system regulating every aspect of both indi vidual and social life. ${ }^{114}$ While this vision of Islam as a 'complete system' is widely shared by revivalists across the contemporary Islamic world, in post tsunami Aceh it takes on new dimensions when read against the backdrop of 'total reconstruction.'

The re definition of Acehnese Islam has included the promotion of rigidified communitarian conceptions of Islam, combined with an intensive scrutiny of the belief, ritual practice, symbolic allegiance, and outward manifestations of moralism among those who claim to belong to the Acehnese umma. The rationale articulated by many behind the Shari'a agenda there is often expressed as a project of "raising awareness" in which, for example, the imposition of physical punishments such as caning are cast not as punitive measures, but rather as "a means of education and construction" for convicted offenders, while also provid ing a warning for society at large (efek jera).115 These attitudes are clearly demonstrated in both the rhetoric and the functional operations of the Sharī'a Police and the Islamic Courts.

The appeal to more general social and cultural norms beyond the sphere of formal law advanced by earlier jurists such as Pound can help us to appreciate in a more expansive way the role of the Shari’a in stitutions in Aceh in remaking Islam in new ways across diverse fields ranging from theology and ritual practice to fashion and mosque archi tecture. There is a distinct logic of discourse and practice underlying the activities of the official institutions of Islamic law in Aceh that has yet to receive the attention it deserves in international scholarship, largely because of the way in which such work has tended to focus almost exclusively on formal legislation and (relatively rare) cases of the application of corporal punishment. However, in increasingly directing its energies and resources toward 'socialization' projects, Aceh's contem porary Sharìa institutions are placed in the service not just of regulat

\footnotetext{
113 Bowen, Islam, Law and Equality, 232.

114 Al Yasa Abubakar, Syari"at Islam, 21-6.

115 Ibid., 203-4.
} 
ing human interaction through discipline and punishment, but also of facilitating the formation of particular religious and behavioral disposi tions among the community at large. These social transformations have the potential to exert far more significant, long-term impacts than the passing of any particular piece of legislation or the ephemeral electoral victory of any political party. Indeed, as Roscoe Pound noted in his introduction to Ehrlich's major work on 'living law', "the inner order maintained by the rules of conduct recognized and generally followed as binding... function notwithstanding the dissolution of a political order." $^{\prime 16}$

Sharīa is particularly powerful for providing such binding rules of conduct because it is, on one level, a sufficiently abstract notion to appeal to anyone who would consider him or herself Muslim. At the same time, however, under this broad assent to Sharīa as an ideal, there are immense spaces for the elaboration of very specific positions on a wide range of social and political-as well as more specifically reli gious-issues. Such a situation allows the possibility, of course, for great manipulation by certain powerful interests. One thinks, for example, of the ways in which, in the United States after the terrorist attacks of September 11,2001, the use of what was on one level an abstract, universally accepted notion of 'freedom' was rhetorically manipulated to quell any opposition to the particular policies of the Bush adminis tration. Similar dynamics have been operative in Aceh, where support ers of the current Shari'a system have branded those Muslim Acehnese critical of particular aspects of its workings as 'opposing Islam.' That being said, however, there is far more to Sharî' a in Aceh than political party power squabbles, and the commitment to using Sharīa as a means to build a new Aceh is passionately held by many involved in the daily application of the contemporary legal system. These Muslims are important participants in what has become a highly contested public sphere of debate over the interpretation and formal role of Islamic law in Acehnese society.

\section{Conclusions}

This essay has sought to demonstrate the need for a reevaluation of the perspectives that have dominated most commentary on Aceh's Islamic legal system to date. It is, of course, clear that the political machinations of various factions have played an important role in both the establishment and the subsequent development of Islamic law in the province, and a considerable number of studies examining aspects of Sharìa politics have been published over recent years. ${ }^{117}$ However a my topic focus on the back and forths of local political drama can obscure an analytic focus on the underlying ideology and institutional logics that inform the work of the system's architects and administrators. Situating their vision of Sharīa within the broader context of social reconstruction in the post tsunami/post conflict period helps us to

116 Pound, "Introduction," xxxiii.

117 For example: Arskal Salim, Challenging the Secular State: e Islamization of Law inModern Indonesia (Honolulu: University of Hawaii Press, 2008), 143-67; Elizabeth F.Drexler, Aceh, Indonesia: Securing the Insecure State (Philadelphia: University of Pennsylvania Press, 2008), 158-68; Kamaruzzaman Bustamam-Ahmad, Islamic Law in Southeast Asia:A Study of its Application in Kelantan and Aceh (Chiang Mai: Silkworm, 2009); Moch. NurIchwan, "Official Ulema and the Politics of Re-Islamization: e Majelis Permusyawaratan Ulama, Sharī'atization and Contested Authority in Post-New Order Aceh," Journal ofIslamic Studies 22.2 (2011): 183-214. 
better appreciate the ways in which Islamic law is deployed as a tool of social engineering.

Looking at this contemporary Islamic legal system as an experiment in social engineering also challenges another common trend in understanding contemporary calls for the implementation of Islamic law: a nostalgic utopian yearning for a return to seventh-century Arabia. In Aceh, this is clearly not the case, and even the occasional rhetorical flourishes referencing Aceh's seventeenth-century 'Golden Age' under Sultan Iskandar Muda are embedded within an ideological framework that is overwhelmingly oriented toward the future, and not the past. ${ }^{118}$ The case of Aceh thus clearly demonstrates the possibility, and the promise, of realigning our perspective on contemporary Muslim projects for the implementation of Islamic law as projects for futureoriented social transformation-rather than simply as a series of reactive measures to perceived 'crises of modernity' and/or the political machinations of rival elites contesting control of state power. Aceh may be exceptional in its implementation of an Islamic legal system in the immediate wake of both war and natural disaster. I would argue, however, that this dramatic setting actually serves to cast sharper relief on the complex array of influences that may be found to animate agendas for the establishment of state Sharì'a in other contexts far removed from its Sumatran shores.

Contemporary debates on Islamic law are formed and developed in constant contact with multiple and diverse discourses on law and society that come from outside of the tradition to inform the ways that increasing numbers of Muslims have come to think about the Sharìa. It is thus crucial for scholars of Islamic law and society to extend their analyses to explore the possible effects of these influences on evolving formulations of Islamic law and its legal methodology. In his widely studied work on legal traditions, Patrick Glenn presents models for understanding both the internal dynamics of, and relations between, complex traditions. In an elegant expression of how he conceptualizes the latter, Glenn writes: any contact between traditions involves exchange of information. If something is known to be out there, it is already in here. e simple existence of information derived from another complex tradition thus blurs the distinction between two traditions. Moreover, if the information is in here, it becomes subject to the multivalent, bridging, complexity of the receiving tradition. It must be dealt with. ${ }^{119}$

In the case of Aceh, we find a striking example of the extent to which such multivalent bridging has functioned to introduce an exceedingly wide range of new discourses into contemporary conversations of Islamic law and reconceptualizations of its role in regulating social change. The integration of elements from such far flung fields as post disaster reconstruction and American sociological jurisprudence into Muslim discourse has had a significant impact on the shape and substance of debates in Aceh. Seeing

118 As, for example, in "Penjelasan atas Qanun Provinsi Nanggroe Aceh Darussalam Nomor 11 Tahun 2002 tentang Pelaksanaan Syari'at Islam Bidang Aqidah, Ibadah, dan Syi'ar Islam," Himpunan Peraturan Perundang Undangan tentang Mahkamah Syar"iyah di ProvinsiNanggroe Aceh Darussalam (Banda Aceh: Mahkamah Syar'iyah Propinsi NAD, 2006),201-9. For a critical overview of Acehnese history and its uses in the present, see R. Michael Feener, "e Acehnese Past and its Present State of Study," in Mapping the Acehnese Past, ed. R. Michael Feener, Patrick Daly, and Anthony Reid (Leiden: KITLV Press, 2011), 1-24.

119 H. Patrick Glenn, Legal Traditions of the World, fourth edition (Oxford: Oxford University Press, 2010), 374. 
these developments thrown into stark relief against the dramatic backdrop of social transformation in post conflict, post tsunami Aceh serves to help us to develop new perspectives on heretofore underappreciated kinds of influences on contemporary interpretations of Islamic law in both theory and practice. 